\title{
ŚWIĘTEGO AUGUSTYNA PRZEŻYWANIE STAROŚCI W ŚWIETLE JEGO LISTÓW
}

26 września 426 r. w obecności duchowieństwa - biskupów: Religiana i Martyniana oraz prezbiterów: Saturnina, Leporiusza, Barnaby, Fortunacjana, Rustyka, Łazarza i Herakliusza, a także tłumnie zgromadzonych wiernych, Augustyn powiedział:

„Wszyscy jesteśmy w tym życiu śmiertelni i dla każdego człowieka ostatni dzień jego życia jest zawsze niepewny. Tym niemniej w niemowlęctwie oczekujemy dzieciństwa; w dzieciństwie czeka się na wiek młodzieńczy, a w wieku młodzieńczym na młodość; w młodości na wiek dojrzały; w wieku dojrzałym na starość. Nie wiemy, czy to się spełni, ale oczekujemy. Starość zaś nie ma przed sobą żadnego wieku, by móc go oczekiwać. Nie wiemy też, jak długo potrwa starość. Pewne jest jednak to, że nie ma żadnego wieku, który mógłby nastąić po starości. Zgodnie z wolą Boga przybyłem do tego miasta w sile wieku, lecz teraz moja młodość już minęła i postarzałem się"”.

Biskup Hippony wygłosił te słowa w Hipponie w Bazylice Pokoju, w wielkim kościele (Basilica Pacis sive maior), jak go sam nazywa². Miał wówczas trochę ponad siedemdziesiąt lat, wiek określony przez psalmistę jako symboliczna meta ludzkiego życia:

„Miarą naszych lat jest lat siedemdziesiąt

lub, gdy jesteśmy mocni, osiemdziesiąt;

a większość z nich to trud i marność:

bo szybko mijają, my zaś odlatujemy" (Ps 90/89, 10).

Charakterystycznym znakiem starości jest brak perspektywy na dalszą nadzie-

${ }^{1}$ Epistola 213, 1, NBA 23, 536: „Omnes in hac vita mortales sumus, et dies huius vitae ultimus, omni homini est semper incertus; verumtamen in infantia speratur pueritia; et in pueritia speratur adolescentia; et in adolescentia speratur iuventus; et in iuventute speratur gravitas; et in gravitate speratus senectus; utrum contingat incertum est; et tamen quod speretur. Senectus autem aliam aetatem quam speret, non habet. Incertum est etiam ipsa senectus quamdiu sit homini; illud tamen certum est, nullam remanere aetatem quae possit succedere senectuti. Quia voluit Deus, ad istam civitatem cum vigore aetatis adveni; sed tamen iuvenis fui, et senui" (przekład własny).

${ }^{2}$ Por. Sermo 325, 2, NBA 33, 794. 
ję, która jest w rzeczywistości normalną rzeczą; starość ją wyklucza. Przypomina to cycerońskie: „Wszyscy pragną dożyć starości, a gdy dożyją, oskarżają ją"3. Nagle Augustyn przerywa tok rozważań poświęcony starości i zaczyna mówić o sobie, wyznając, że odnajduje siebie starym w momencie rezygnacji z biskupiego tronu, a przecież, kiedy go przyjmował, był młody i pełen sił. Upust bardzo ludzki wobec twardego rachunku sumienia, „redde rationem”

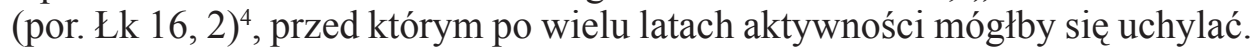
Można powiedzieć, że Biskup Hippony jest szczery aż do bólu, ale już wcześniej możemy znaleźć u niego analogiczne akcenty, zwłaszcza w korespondencji sięgającej czasu poprzedzającego ten okres.

„Sentyment czasu” pojawia się w korespondencji ze św. Hieronimem. Ten ostatni w kontekście polemiki z Rufinem tak oto pisze w 402 r. do św. Augustyna:

„Poza tym powinieneś darzyć miłością tego, który Cię kocha, i w dziedzinie Pisma Świętego Ty, człowiek młody, nie powinieneś prowokować mnie - starca. Stawałem i ja niegdyś do zawodów i przebiegłem, ile tylko mogłem, a teraz Ty biegniesz i wielkie przemierzasz przestrzenie, a mnie należy się odpoczynek; zresztą - jeśli za pozwoleniem Twoim i uczciwszy Cię można tak powiedzieć, żeby nie wyglądało, że tylko Ty jeden zacytowałeś mi coś z poetów, pamiętaj o Daresie i Entellu ${ }^{5}$ oraz o znanym przysłowiu, że „wół zmęczony silniej stawia stopę". Ze smutkiem podyktowałem te słowa; obym zasłużył na Twe uściski i przez wzajemną rozmowę albo Ciebie czegoś nauczył, albo sam się dowiedział"'.

Jak widać, strategia retoryczna towarzyszy św. Hieronimowi wiernie w całym jego stylu i ludzkich odniesieniach: przeciwstawia siebie starca św. Augustynowi młodzieńcowi, czyni aluzje do literatury starożytnej i swego wieku. Hieronim miał wtedy ok. 55 lat, Augustyn - 48, a więc w pełni sił. Przytoczenie z Wergiliusza przywołuje epizod Daresa i Entella, przykład starości, by uderzyć w młodość. Samą tezę odpiera przy pomocy przysłowia. Końcowe

${ }^{3}$ Cicero, De senectute 4, 12: „Senectutem ut adipiscantur, omnes optant, eandem accusant adepti”; por. też Cicero, De senectute 68: „At senes ne quos speret quidem habet”.

${ }^{4}$ Por. Augustinus, Enarrationes in Ps. 48, 1, 12, NBA 25, 1212; Sermo 347, 2, NBA 32/2, 710; Sermo 302, 13, NBA 33, 502; Contra Faustum 32, 19, NBA 14/2, 722; Contra secundam Iuliani responsionem imperfectum opus VI 27, NBA 19/2, 1176.

${ }^{5}$ Entel i Dares to bliżej nieznani towarzysze Eneasza. Starzec Entel odnosi w zapasach zwycięstwo nad jeszcze stosunkowo młodym Daresem, por. Vergilius, Aeneis V 362-484.

${ }^{6}$ Hieronymus, Epistola 102, 2, thum. J. Czuj, ŹMT 61, 115 lub w: Św. Augustyn, Listy, Pelplin 1991, 384 (= Augustinus, Epistola 68, 2, NBA 21, 552): „Superest ut diligas diligentem te, et in Scipturarum campo iuvenis senem non provoces. Nos nostra habuimus tempora, et cucurrimus quantum potuimus. Nunc, te currente, et longa spatia transmeante, nobis debetur otium: simulque (ut cum venia et honore tuo dixerim) ne solus mihi de poetis aliquid proposuisse videaris, memento Daretis et Entelli, et vulgaris proverbii, quod bos lassus fortius figat pedem. Tristes haec dictavimus. Utinam mereremur complexus tuos, et collatione mutua vel doceremus aliqua, vel disceremus!”. 
spojrzenie smutne, bo nie dochodzi do spotkania „facies in faciem”. Augustyn odpowiadając trochę później, posługuje się Hieronimowym żartem „,iam senex", chociaż nie miał jeszcze wtedy 50 lat, patrząc na czas, kiedy był iuvenis, wskazał na swój List 28 skierowany do Hieronima, kiedy miał lat 40:

„iuvenem me ad tuam Sanctitatem scripsisse meminerim", „et ecce iam senes, necdum rescripta meruerim"s.

Augustyn podejmuje ponownie topiczne przeciwstawienie starości wobec młodości, wypływające z przytoczenia wergiliańskiego o Daresie i Entellu, usiłując w ten sposób osłodzić ton korespondencji:

„Po cóż więc mam się lękać ostrych może, lecz zapewne uzdrawiających twych słów, jakby rękawic Entella9? Bił on Daresa nie po to, aby go pielęgnować, lecz aby zwyciężyć. Ja zaś nie będę czuł bólu, jeśli spokojnie przyjmę Twą naganę, która ma mnie wyleczyć. Być może, że z powodu słabości, czy to ogólnoludzkiej, czyli tylko mojej, nie będę mógł uniknąć pewnej przykrości, nawet gdy nagana jest słuszna; ale lepiej dla mnie będzie ją znieść, tak jak lepiej narazić się na ból przecinając wrzód, niż z obawy bólu wcale go nie leczyć [...]. Chociaż więc wydajesz się sobie podobny do wołu (bos), spocony w owocnej pracy na polu Pańskim, zmęczony wiekiem (lassus senectute), ale pełen sił ducha - oto jestem; jeśli powiedziałem coś niewłaściwego, postaw silniej nogę. Ze względu na Twój wiek nie będę się Tobie sprzeciwiał, bylebyś starł moją winę jak plewy"10.

Augustyn powtarzając żart Hieronima, przyjmuje go z pokora, przyznając się jakby do własnej winy - przypisywanego mu grubiaństwa, życząc sobie zniszczenia tego grubiaństwa przez zmęczonego woła (bos lassus) depcącego plewy. Zaraz potem z prawdziwą finezją nie zapomina zauważyć, że epizod wergiliański szanuje zwycięstwa i porażki, jest krytyczny i opanowany, wreszcie konstruktywny, bo wskazuje na rozwój duchowy. Nieco później Hieronim wraca do tego wydarzenia pisząc do Augustyna:

„Wreszcie nie chciałem usłyszeć od Ciebie słusznego zapytania: Jak to? Czy widziałeś mój list i zauważyłeś w podpisie znaki znanej Ci ręki, że tak łatwo obracasz przyjaciela i czyjejś złośliwości czynisz obelgę przeciwko mnie? Toteż, jak przedtem napisałem, albo przyślij ten sam list podpisany własnoręcznie, albo przestań wyzywać ukrywającego się w celi starca. Jeśli zaś chcesz szermować i popisywać się swoją uczonością, szukaj ludzi młodych, wymownych i nieprzeciętnych; takich podobno jest w Rzymie bardzo

\footnotetext{
${ }^{7}$ Augustinus, Epistola 28, 4 i 6, NBA 21, 178 i 180.

${ }^{8}$ Augustinus, Epistola 73, 5, NBA 21, 584.

${ }^{9}$ Por. Vergilius, Aeneis V 362-384.

${ }^{10}$ Augustinus, Epistola 73, 4, NBA 21, 584, thum J. Czuj, w : Św. Augustyn, Listy, s. 397 (= Hieronymus, Epistola 110, 4, ŹMT 61, 195). Augustyn napisał ten list w 404 roku.
} 
wielu. Oni potrafią walczyć z Tobą, nie ulękną się podjąć wraz z biskupem trudu dysputy nad Pismem Świętym. Ja, niegdyś żołnierz, dziś już weteran, mam obowiązek tylko chwalić sukcesy zarówno Twoje, jak i innych, sam będąc słaby na ciele nie mogę stawać do walki; nie chciałbym zresztą, jeślibyś się zbyt często domagał odpowiedzi, przypominać tego zdarzenia, jak to Kwintus Maksymus cierpliwością swoją złamał pewnego młodzieńczej werwy Hannibala ${ }^{11}$. Czas nad wszystkim i nad umysłem działa: Pomnę, gdym był chłopięciem, cały dzień od rana rym nucił, dziś ich mnoga liczba zapomniana. Już Mery, głos twój ginie ${ }^{12}$. Tak i ten Galadyjczyk Berselaj - żeby przypomnieć przykład z Pisma Świętego - wyrzekł się łaski i wszelkich dobrodziejstw króla Dawida na rzecz młodocianego syna, wskazując, iż starość nie powinna ubiegać się o takie dobra ani przyjmować ich w darze (por. 2Sm 19, 31) [...]. Powtarzam to, co czuję: prowokujesz starca, wyzywasz milczącego i wydaje się, że chełpisz się swoją erudycją. Nie wypada jednak w moim wieku uchodzić za złośliwego względem tego, dla kogo raczej powinienem być życzliwy"13.

Hieronim łączy sprawy przykre z przyjemnymi. Z jednej strony podkreśla, że z powodu starości jest zmęczony dysputą i nie powinno go się złościć, z drugiej z kolei przytacza przykłady topiczne starych ludzi cierpliwych, pokonujących młodych zuchwałych: Entel zwycięża Daresa, Kwintus Maksymus - Hannibala. Daje też przykład z Biblii, pokazując wielkość i dystans do wielu spraw człowieka starego.

${ }^{11}$ Por. Livius, Ab urbe condita XXII 12-18, thum. M. Brożek: Tytus Liwiusz, Dzieje Rzymu od założenia Miasta, Biblioteka Przekładów z Literatury Antycznej 20, Wrocław 1974, 78-86.

${ }^{12}$ Por. Vergilius, Bucolica IX 51-54, tłum. Z. Abramowiczówna, Warszawa -Wrocław 2006, przedruk z r. 1953, Seria II BN nr 83, s. 60. Meris, sługą Manalkasa Wergiliusza, nagle urywa, bo dalszego ciągu nie pamięta i skarży się, że starość odebrała mu pamięć.

${ }^{13}$ Hieronymus, Epistola 105, 3 i 5, tłum. J. Czuj, ŹMT 61, 121-122, lub w: Św. Augustyn, Listy, s. 393-394 (=Augustinus, Epistola 72, 3 i 5, NBA 21, 574 i 576): „Ad extremum ne tu iure expostulares et diceres: Quid enim? epistolam meam videras, et notae tibi manus in subscriptione signa deprehenderas, ut tam facile amicum laederes, et alterius malitiam in meam verteres contumeliam? Igitur ut ante iam scripsi, aut mitte eamdem epistolam tua subscriptam manu; aut senem latitantem in cellula lacessere desine. Sin autem tuam vis vel exercere, vel ostentare doctrinam, quaere iuvenes, et disertos, et nobiles, quorum Romae dicuntur esse quam plurimi, qui possint et audeant tecum congredi, et in disputatione sanctarum Scipturarum iugum cum episcopo ducere. Ego quondam miles, nunc veteranus, et tuas et aliorum debeo laudare Victoria, non ipse rursus effeto corpore dimicare (Horatius, Ep. 1, 1, 3); ne, si me frequenter ad rescribendum impuleris, illius recorder historiae, quod Annibalem inveniliter exsultantem, Q. Maximus patientia sua fregerit (Titus Livius 22, 12-18).

Omnia fert aetas, animum quoque. Saepe ego logos / Cantando puerum memini me condere soles: / Nunc oblita mihi tot carmina; vox quoque Moerim / Iam fugit ipsa (Verg., Bucol. 9, 51- 54).

Et, ut magis de Scripturis sanctis loquar, Berzellai ille Galaadites, regis David beneficia omnesque delicias iuveni delegans filio, ostendit senectutem haec appetere non debere, nec oblata suscipere [...]. Rursum dico quod sentio: provocas senem, tacentem stimulas, videris iactare doctrinam. Non est autem aetatis meae, putari malevolum erga eum cui magis favere debeo". 
Wreszcie w kolejnym liście napisanym do Augustyna, daje Hieronim odpowiedź na różne ważne kwestie przesłane mu we wcześniejszej korespondencji, powołując się ponownie na argument własnego wieku starczego:
„Nie podburzaj przeciwko mnie niedoświadczonych, którzy Ciebie szanują jako biskupa przemawiającego w Kościele i odnoszą się do Ciebie z czcią należną kapłaństwu, mnie zaś lekceważą, bo jestem u schyłku życia i niemal zgrzybiały, i pragnę tylko klasztornego wiejskiego ustronia. Szukaj sobie ta- kich, których byś mógł uczyć i ganić. Do mnie bowiem z trudem dochodzi dźwięk Twego głosu, tak wielką przestrzenią morza i lądów jestem od Ciebie oddzielony"14.

Przesłanie pozostaje takie same. Hieronim jest stary i nie pragnie być niepokojony przez polemiki. Pomimo wielkiego szacunku wobec biskupiej godności św. Augustyna nie chce dać się wciągnąć w polemikę. Wymiana listów Augustyna z Hieronimem ukazuje szacunek ze strony Biskupa wobec starca mnicha.

Augustyn pisząc na przełomie lat 411/ 412 list do Marcelina, komisarza cesarskiego, któremu dedykował De civitate Dei, porusza w nim zaproponowany przez korespondentów temat możliwości zmiany Bożej Opatrzności:

\begin{abstract}
„Czyż po zimie nie następuje lato ze stopniowym wzrostem ciepła? Czyż po nocnych godzinach nie następują dzienne? Ile razy zmieniają się nasze lata? Dzieciństwo kończy się bezpowrotnie na rzecz młodzieńczości, po niej następuje młodość i nie jest przeznaczona na pozostanie; starość, która kładzie kres młodości, kończy się śmiercią. Wszystkie te sprawy podlegają zmianie, ale nie zmienia się postanowienie Bożej Opatrzności, dzięki której te sprawy ulegają zmianie. Uważam, że nie zmienia się porządek racjonalny uprawy roli, kiedy rolnik postanowi w lecie coś innego niż polecił w zimie, i nie zmienia porządku życia ten, kto wstaje rano po nocnym wypoczynku. Inne rady daje nauczyciel młodzieńcowi niż zwykł je dawać chłopcu. Nauka pozostaje stała, chociaż zmieniają się przepisy, nie zmieniona, lecz wydaje nowe rozporządzenia ${ }^{15}$.
\end{abstract}

${ }^{14}$ Hieronymus, Epistola 102, thum. J. Czuj, ŹMT 61, 213, lub w: Św. Augustyn, Listy, s. 414 (=Augustinus, Epistola 75, 18, NBA 21, 626: „Neque mihi imperitorum plebeculam concites, qui te venerantur ut episcopum, et in Ecclesia declamantem, sacerdotii honore suspiciunt; me autem, aetatis ultimae, et pene decrepitum, ac monasterii et iuris secreta sectantem, parvipendunt; et quaeras tibi, quos doceas sive reprehendas. Ad nos enim, tantis maris atque terrarum a te divisos spatiis, vix vocis tuae sonus pervenit".

${ }^{15}$ Augustinus, Epistola 138, 2, NBA 22, 172: „Nonne hiemi aestas, addito sensim calore, succedit? Nonne diurnis tempora nocturna vertuntur? Quoties nostrae variantur aetates! adolescentiae pueritia non reditura cedit; iuvetus adolescentiae, non mansura succedit; finiens iuventutem senectus morte finitur. Haec omnia mutantur, nec mutatur divinae providentiae ratio, qua fit ut ista mutentur. Non autem, opinor, cum agricola aestate aliud iusserit, quam iusserat hieme, ratio mutatur agriculturae. Et cum mane surgit qui nocte quiescebat, vitae consilium non mutavit. Aliud magister adoles- 
Augustyn wyjaśnia ponadto pewną myśl, według której rzeczy dobrze uczynione nie podlegają zmianom, chyba że zaistnieje jakaś słuszna racja. „Recte [...] facta [...] mutari nisi iniuste non posse" - jest to teza stoicka. „Recte facta” występuje już u Cycerona ${ }^{16}$ - termin techniczny к $\alpha \tau o \rho \theta \omega ́ \mu \alpha \tau \alpha$ - czyny pozytywnie odnotowane według etyki Portyku ${ }^{17}$. Argumentacja Augustyna opiera się na założeniu, że cała rzeczywistość jest w ciagłym ruchu, jak to można zauważyć w prostej antropologicznej obserwacji różnych okresów rozwoju człowieka: pueritia, adolescentia, iuventus, senectus. Tę ostatnią zamyka śmierć. $Z$ powodu odmiennej sytuacji poszczególnych okresów życia, można narzucić zróżnicowanie wychowawcze odnośnie do wieku, podczas gdy Opatrzność Boża pozostaje wolna od każdego możliwego ruchu. Te zmiany zewnętrzne i wewnętrzne człowieka w ciągu życia pokazał Augustyn na wielu stronach swych Wyznań.

Odwołanie się do następstw fizycznych przebiegu czasu, jako znaku i potwierdzenia praw uniwersalnych, ukazuje też w kontekście innego listu, skierowanego do tego samego adresata, który prosi Augustyna o wyjaśnienie pewnego zdania z jego traktatu De libero arbitrio ${ }^{18}$. Augustyn odpowiada słowami Salustiusza:

„Wtedy więc dusza będzie dowolnie kierowała ciałem duchowym, teraz zaś nie dowolnie, lecz jak prawa powszechne pozwalaja, dzięki którym postanowiono, że ciała „rosną i umierają, wzrastają i starzeją się"

Podobnie wyraża się w Confessiones:

„Jak słońce, wschodzą te rzeczy i zachodzą. Gdy wschodzą to jakby zaczynają istnieć. Wzrastają potem aż do czasu, w którym osiagają doskonałość, a po jej osiagnięciu zaczynają starzeć się i giną. Nie wszystkie osiagają starość, ale wszystkie muszą umrzeć. Wtedy więc, gdy wchodza, rozpoczynają drogę istnienia, na której im szybciej wzrastają ku swej pełni, tym też szybciej skłaniają się potem ku nieistnieniu. Takiemu podlegają prawu. Takie dla nich przeznaczyłeś istnienie, gdyż są częścią wielkiej całości. Części tej całości

centi quam puero solebat, imposuit. Doctrina igitur constans, mutato praecepto, non mutata mutavit instructionem" (przekład własny).

${ }^{16}$ Cicero, De finibus bonorum et malorum III 7, 24, thum. W. Kornatowski: Marcus Tullius Cicero, Pisma filozoficzne, III, Biblioteka Klasyków Filozofii, Warszawa 1961, 297.

${ }^{17}$ Por. A. Cacciari, Agostino e la vecchiaia, w: Senectus nell'antichità, ed. U. Mattioli, vol. 3: Senectus. La vecchiaia nell'antichità ebraica e cristiana, Bologna 2007, 517.

${ }^{18}$ Por. Augustinus, De libero arbitrio III 11, 33, NBA 3/2, 326, thum. A. Trombala: $O$ wolnej woli, w: Św. Augustyn, Dialogi filozoficzne, Kraków 2001, 611.

${ }^{19}$ Epistola 143, 6, NBA 22, 336: „Tunc itaque spiritale corpus reget omni modo pro arbitrio; nunc vero non omni modo, sed sicut leges universitatis sinunt, per quas constitutum est ut corpora orta occidant, et aucta senescant” - cytat z Salustiusza (De bello Iugurtino 2, 3): „Postremo corporis et fortunae bonorum ut initium sic finis est, omniaque orta occidunt et aucta senescunt”; por. też Epistola 166, 5, 14, NBA 22, 736; De civitate Dei XIII 16, 17, NBA 5/2, 248, $250,252$. 
nie istnieją wszystkie jednocześnie, lecz kolejno ustępują sobie i następują po sobie, i w ten sposób stanowią ową wszechcałość, której są elementami”20.

Najprawdopodobniej Augustyn przejął cytat z Salustiusza od św. Cypriana ${ }^{21}$, autora, którego bardzo cenił22, chcąc w ten sposób ożywić i rozszerzyć temat, ujmując go bardziej eschatologicznie jako starość kosmiczną ${ }^{23}$.

W liście napisanym po roku 414 wspólnie z Alipuszem do starego Maksyma, niedawnego konwertyty z arianizmu, Augustyn pochwala postanowienie, odpierające dawny błąd doktrynalny:

„Może potępią Ciebie, ponieważ wstąpiłeś do wspólnoty Kościoła katolickiego w tak zaawansowanym wieku, chociaż raczej powinni Cię podziwiać i uszanować, bo pokonałeś bardzo stary błąd siłą - można tak powiedzieć młodzieńczą w starości (senili iuventute)"24.

Do zwrotu „senilis iuventus”25 nawiązuje Augustyn w kontekście pochwalnym, przywołując wyrażenie topiczne „senex puer”, podtrzymujące jakość właściwą wieku młodzieńczemu ${ }^{26}$.

W liście napisanym w 416 r. do Jana, biskupa Jerozolimy, Augustyn prosząc o przesłanie postanowień synodu w Diospolis, który odbył się przeciw Pelagiuszowi w grudniu 415 r., temat starości przenosi na kontrowersję doktrynalną. Przywołuje w nim przypisywany Pelagiuszowi traktat De natura, przekazany biskupowi Hippony przez uczniów Pelagiusza - Tymazjusza i Jakuba, oraz odparcie przez niego w De natura et gratia poglądów herezjarchy ${ }^{27}$, który tak twierdził w swym dziele:

„Albo jeśli być może, ponieważ powiedział [Pelagiusz], że nikt od niemowlęctwa aż do starości nie zgrzeszył, zatem mówi, że Abel nie zgrzeszył, ponieważ z Pisma Świętego wynika, że nie osiagnął starości. Lecz nie taki jest

${ }^{20}$ Confessiones IV 10, 15, NBA 1, 96, thum. Z. Kubiak: Święty Augustyn, Wyznania, Warszawa 1987, 73.

${ }^{21}$ Por. Cyprianus, Ad Demetrianum 3, CCL 3A, 36-37: „Haec sententia mundo data est, haec Dei lex est ut omnia orta occidant et aucta senescant et infirmentur fortia et magna minuantur et cum infirmata et deminuta finiantur” (= „Takie postanowienie otrzymał świat, takie jest prawo Boga, że wszystko, co powstało do życia, umiera, a co wzrosło, starzeje się i co, jest silne, słabnie, a co wielkie, maleje, i kiedy staje się słabe i małe, przestaje istnieć" - przekład własny).

${ }^{22}$ Por. A. Eckmann, Kultura klasyczna u św. Augustyna, VoxP 6 (1986) z. 10, 59

${ }^{23}$ Por. Cacciari, Agostino e la vecchiaia, s. 518.

${ }^{24}$ Augustinus, Epistola 170, 10, NBA 22, 808: „An forte contemnunt te quia in Ecclesiae catholicae participationem hac aetate venisti, cum te amplius debeant admirari, atque venerari, quia vetustissimum errorem senili quadam iuventute vicisti" (przekład własny).

${ }^{25}$ Por. Plinius Secundus, Naturalis Historia VII 51(52), 171: „senilem iuventam praematurae mortis esse signum".

${ }^{26}$ Por. Cacciari, Agostino e la vecchiaia, s. 519.

${ }^{27}$ Por. Augustinus, Epistola 179, NBA 22, 884-894; Epistola 177, 6, NBA 22, 864; Epistola 168 (Timasii et Iacobi ad Augustinum), NBA 22, 782. 
sens jego słów, ponieważ powiedział, że na początku wcześniejsze jego życie było grzeszne, późniejsze zaś mogło być bez grzechu. On utrzymuje, że nie powiedział, że jest ktoś, kto nie popełnił grzechu od niemowlęctwa aż do starości, ale tylko, że odwróciwszy się od grzechu własnym wysiłkiem i wsparty Bożą łaską, może żyć z dala od grzechu. Kiedy bowiem mówi: «od grzechów odwrócony», pokazuje, że wcześniej żył w grzechach. Wyznaje więc, że Abel zgrzeszył w pierwszym okresie swego życia, o którym mówi, że był wolny od grzechów. Niech dobrze spojrzy na swoją książkę, gdzie wiadomo, że powiedział to, co utrzymuje w tej obronie, że nie powiedział"28.

Obstawanie przy grzeszności od niemowlęctwa aż do starości, łączy się z tematem bezgrzeszności (impeccantia), jednym z punktów zapalnych sporu pelagiańskiego i w następstwie obszernych traktatów antypelagiańskich św. Augustyna ${ }^{29}$.

Niedługo potem, bo w roku 413, Augustyn pisał do Cecyliana, następcy Marcellina na stanowisku komisarza cesarskiego:

„Do całej mojej słabości, o której wiedzą wszyscy, którzy mnie znają bardziej rodzinnie, doszła także starość, która jest wspólną słabością (communis infirmitas) rodzaju ludzkiego" 30 .

Wyrażenie ,communis infirmitas” występujace częściej u św. Augustyna ${ }^{31}$, może mieć pochodzenie cycerońskie ${ }^{32}$.

59-letni Augustyn skarży się często na obowiązki i użala się nad zbliżającą się starością, która według starożytnych zaczynała się od 60 roku życia, o czym sam pisze ${ }^{33}$. Staje się to okazją, że Biskup Hippony zaczyna częściej mówić o swoim podeszłym wieku. W liście do biskupa Auxiliusza napisanym w latach 415-420, po przekroczeniu sześćdziesiątki, jakby pomniejszał swój wiek i doświadczenie:

${ }^{28}$ Augustinus, Epistola 179, 9, NBA 22, 892-894: „Aut si forte, quoniam dixit ab infantia usque ad senectutem, ideo dicat Abel non pecasse, quia nec senuisse monstratur. Non hoc indicant verba eius, ab initio priorem vitam dixit peccatricem, posteriorem vero posse esse sine peccato. Ait enim non se dixisse: «quoniam inveniatur quis ab infantia usque ad senectutem, qui non peccaverit; sed quoniam a peccatis conversus labore proprio, et gratia Dei adiutus potest absque peccato esse». Cum enim dicit: «a peccatis conversus», ostendit priorem vitam in peccatis agi. Fateatur ergo quod peccaverit Abel, cuius prima fuit in saeculo, quam fatetur non carere peccatis, et respiciat librum suum, ubi eum dixisse constat, quod ait in hac defensione: «Non diximus»" (przekład własny).

${ }^{29}$ Por. Św. Augustyn, Łaska Wiara Przeznaczenie. Przełożył i opracował W. Eborowicz, POK 27, Poznań - Warszawa - Lublin, 1971.

${ }^{30}$ Augustinus, Epistola 151, 13, NBA 22, 516: ,infirmitati meae propriae, quae nota est omnibus qui familiarius me noverunt, accessit etiam senectus, quae generis humani est communis infirmitas" (przekład własny).

${ }^{31}$ Por. np. Epistolae 153, 4; 264, 3; Enarrationes in Ps. 141, 1.

${ }^{32}$ Por. Cicero, De inventione II 101; Cacciari, Agostino e la vecchiaia, s. 520.

${ }^{33}$ Por. Augustinus, De diversis quaestionibus LXXXIII 58, 2, NBA 6/2, 120: „,cum a sexagesimo anno senectus dicatur incipere". 
„Oto jestem gotowy uczyć się, ja starzec od młodzieńca; ja biskup od wielu lat od kolegi, który jeszcze nie jest rok biskupem" ${ }^{34}$.

I konkluduje:

„Miłosierdzie zaś Boga naszego jest nie tylko zdolne wysłuchać mojej modlitwy, aby mój smutek nie powiększał się z waszego powodu, lecz raczej zostało uzdrowione to, co powstało, i niech cię wzmocni swoją łaską i rozweseli twoją młodość nie potępiającą mojej starości"35.

W liście do papieża Celestyna z roku 423, kiedy Biskup Hippony zbliżał się już do siedemdziesiątki, posługuje się konsolacją w kontekście, kiedy mówi o strachu i smutku z uczuciem zadumy obserwując własną starość:

„Jeśli zaś ulżysz zabójczemu strachowi i smutkowi wiernych Chrystusa, którzy mieszkają w tej okolicy, oraz udzielisz pocieszenia mojej starości aktem sprawiedliwości i miłosierdzia, odpłaci ci za dobro dobrem w tym i przyszłym życiu Ten, który przez ciebie nam w tym utrapieniu przyszedł z pomocą i który ciebie ustanowił na tej siedzibie biskupiej"36.

Natomiast na przełomie grudnia-stycznia 425/426, kiedy już przekroczył siedemdziesiątkę, Augustyn mówił do swych diecezjan:

„Jak bowiem widzicie, wiekiem powoli się starzeję, a słabością ciała jestem już dawno starcem"37.

W ostatnich latach życia Biskup Hippony pisywał coraz częściej negatywnie o swej starości, jak np. w liście z 428 r. do Dariusza, komesa Afryki, utożsamiając zimno wiosny z zimnym wiekiem:

„Ponieważ mnie słabość ciała i podwójne zimno, to jest zimy i wieku, nie pozwala z tobą rozmawiać w cztery oczy, dlatego cię nie zobaczyłem"38.

${ }^{34}$ Por. Augustinus, Epistola 250, 2, NBA 23, 862: ,en adsum, senex a iuvene et episcopus tot annorum a collega necdum anniculo paratus sum discere" (przekład własny).

${ }^{35}$ Por. Augustinus, Epistola 250, 3, NBA 23, 864: „Potens est autem misericordia Dei nostri, quae et me exaudiat orantem, ne mea tristitia de vobis augeatur, sed potius quae est exorta sanetur; et exigat per gratiam suam, et laetificat iuventutem tuam non contemnentem senectutem meam" (przekład własny).

${ }^{36}$ Augustinus, Epistola 209, 10, NBA 23, 502, 504: „Si autem et membra Christi, quae in illa regione sunt, ab exitiabili timore ac tristitia recreaveris, et meam senectutem hac misericordi iustitia fueris consolatus, retribuet tibi, et in praesenti et in futura vita, bona pro bonis, qui per te nobis in ista tribulatione succurrit et qui te in illa Sede constituit" (przekład własny).

${ }^{37}$ Augustinus, Sermo 355, 7, NBA3 4, 256: „Ego, sicut videtis, per aetatem modo senui; per infirmitatem corporis olim sum senes" (przekład własny).

${ }^{38}$ Augustinus, Epistola 229, 1, NBA 23, 708: „quia me infirmitas corporis et geminum frigus, id est hiemis et aetatis, non sinit coram tecum colloqui, ideo non te vidi" (przekład własny); por. np. Epistolae 28, 1; 118, 34; 122, 1; 249; zob. też Vergilius, Aeneis V 395-396: ,gelidus tardante senecta sanguis hebet, frigentque effetae in corpore vires”, powtórzył Silius Italicus w Punica V 568: „fri- 
Jednak nawet wtedy, kiedy pisał o swej słabej kondycji zdrowotnej i źródle nie dającego się uniknąć smutku, Augustyn nie rezygnował z gry słownej, z retorycznych żartów (linguosae artes), które są znakomite i służą dla usprawiedliwienia własnej nieobecności w oficjalnej ceremonii. Tak m.in. czyni w krótkim liście skierowanym do biskupa Nobiliusza w zimie 429/430 roku:

„Mógłbym przybyć, gdyby nie było zimy; mógłbym wzgardzić zimą, gdybym był młodzieńcem; bowiem albo żar wieku (fervor aetatis) zniósłby surowość pory roku (rigorem temporis), albo żar lata (fervor aestatis) łagodziłby zimno wieku (frigus aetatis). Teraz zimą nie zniosę tak długiej podróży z chłodną starością (cum annositate algida), którą niosę ze sobą"'.

Można tu odnotować dikolon: „frigus aetatis fervor aestatis”, zbudowany z dwóch symetrycznych zwrotów (nominativus + genetivus, schemat: ABAB), tworząc aliterację, paronomasticon i homoioteleuton, prawdziwą grę słowną. Taki był św. Augustyn, on nigdy nie przestał być retorem² ${ }^{2}$ ale - niestety, nawet retoryka nie zdołała rozproszyć gorzkości tkwiącej w nim z powodu zimnej starości (annositas algida), co wyrażał na poziomie syntaksy, używając imperfectum irrealis i oddając w ten sposób niemożliwość bycia młodzieńcem i działania na sposób młodzieńczy: nie może już uczynić tego, co mógł, kiedy miał lat dwadzieścia. O wieku starczym pisał dużo wcześniej do poganina, człowieka o dużej erudycji, starca Nektariusza:

„Już się nie dziwię, a nawet cię chwalę, że choć ziębną twe członki na skutek starczej słabości, duch twój płonie miłością ojczyzny"3.

Wtedy był jeszcze względnie młody, miał 54 lata. Łatwiej pisać o starości czyjejś niż własnej, teraz jest stary, może jedynie wspominać lata młodzieńcze. Duch ochoczy, ale ciało mdłe. (por. Mt 26, 41). Św. Augustyn przeżył siedemdziesiąt sześć lat, z tego jako prezbiter i biskup niemal czterdzieści. W czasie swej ostatniej choroby, kiedy już leżał w łóżku, przez cały czas oddawał się modlitwie, odmawiając umieszczone na ścianie naprzeciwko niego psalmy

gentem [...] senectam”. Pojęcie starości jako „wieku zimnego” ma swe źródło medyczne u Celsusa, Med. II 1: „senectutis frigore”.

${ }^{1}$ Augustinus, Epistola 269, NBA 23, 956: „Possem venire si hiems non esset; possem hiemem contemnere, si iuvenis essem; aut enim ferret rigorem temporis fervor aetatis, aut temperaret frigus aetatis fervor aestatis. Nunc hieme iter tam prolixum non suffero cum annositate algida quam mecum fero" (przekład własny).

${ }^{2}$ Por. A. Eckmann, Św. Augustyn - wirtuoz języka i stylu (List 150), VoxP 11-12 (1991-1992) z. 20-23, 451-462.

${ }^{3}$ Augustinus, Epistola 91, NBA 21, 782: „Iam senio frigescentibus membris, fervere animum tuum patriae caritate, nec miror et laudo"; por. A. Eckmann, Dialog świętego Augustyna ze światem pogańskim w świetle jego korespondencji, Lublin 1987, 37-48, 206-210, 242-245. 
pokutne $\mathrm{W}$ obecności przyjaciół i bliskich zasnął w Panu „nasycony dobrą starością" (enutritus in bona senectute) ${ }^{4}$.

Św. Augustyn wyróżniał sześć okresów życia ludzkiego: niemowlęctwo (infantia), dzieciństwo (pueritia), wiek młodzieńczy (adolescentia), młodość (iuventus), dojrzałość (gravitas) i starość (senectus). Każdy z tych okresów ma jakąś perspektywę, brakuje jej jedynie starości. Augustyn czyni rachunek sumienia. „Sentyment czasu” pojawia się w korespondencji ze św. Hieronimem, który siebie starca przeciwstawia św. Augustynowi młodzieńcowi, czyniąc aluzje do literatury starożytnej i swego wieku. Wymiana listów między tymi Ojcami Kościoła wyraża ze strony Augustyna szacunek wobec starca mnicha. Cała rzeczywistość jest w ciagłym ruchu, jak to można zauważyć w prostej antropologicznej obserwacji różnych okresów rozwoju człowieka: dzieciństwo (pueritia), wiek młodzieńczy (adolescentia), młodość (iuventus) i starość (senectus); tę ostatnią zamyka śmierć. Starość jest wspólną słabością (communis infirmitas) rodzaju ludzkiego.

Biskup Hippony użalał się często na zbliżającą się starość, która według starożytnych zaczynała się od 60 roku życia. Przekroczenie sześćdziesiątki stało się dla niego okazją, by mówić lub pisać, że jest gotów uczyć się od wiele młodszego kolegi w biskupstwie. Kiedy zaś przekroczył siedemdziesiątkę, mawiał, że wiekiem powoli się starzeje, a słabością ciała jest już dawno starcem.

\section{SAINT AUGUSTINE'S OLD AGE SURVIVAL IN THE LIGHT OF HIS LETTERS}

\section{(Summary)}

Saint Augustine distinguished six periods of human life: infancy (infantia), childhood (pueritia), adolescence (adolescentia), young adulthood (iuventus), middle age (gravitas) and old age (senectus). Each of those periods has a perspective. Only in old age there is lack of it. Augustine makes the examination of conscience. Sentimental mood appears in the mail from the Saint Jerome, who poses himself as an old man in the opposition to Augustine as a young man, making allusions to ancient literature and his age. Exchange of letters between the Fathers of the Church records Augustine's respect toward an old man, the monk. The entire reality is in continuous motion, as you can see in a simple anthropological observation of different periods of human development: childhood (pueritia), adolescence (adolescentia), young adulthood (iuventus), old age (senectus). The latter closes the death. Old age is a common weakness (communis infirmitas) of mankind. Augustine complained frequently on the impending old age, which according to ancients starts with 60 year old.

${ }^{4}$ Possidius, Vita Sancti Augustini 31, PL 32, 64, tłum. P. Nehring: Possydiusz z Kalamy, Żywot św. Augustyna, ŹM 26, Kraków 2002, 127. 
Turning sixty gave him an opportunity to say that from now on he is willing to learn from much younger colleague from bishopric. Next, when he turned seventy he used to say that with increasing age he gradually gets old, but when it comes to the weakness of his body he has been an old man from a long time. 